\title{
Evaluation of Some Cow-based Bio-enhancers and Botanicals for Organic Cultivation of Summer Groundnut
}

\author{
Mahmad A. Shekh*, Ratilal K. Mathukia, Bhimjibhai K. Sagarka and Sunil K. Chhodavadia
}

Dept. of Agronomy, College of Agriculture, Junagadh Agricultural University, Junagadh, Gujarat (362 001), India

\section{Corresponding Author}

Mahmad A. Shekh

e-mail: mashekh@jau.in
Article History

Article ID: IJEP0231

Received in $28^{\text {th }}$ October, 2017

Received in revised form $2^{\text {nd }}$ February, 2018

Accepted in final form $10^{\text {th }}$ February, 2018

\section{Abstract}

A field experiment was conducted in summer season of 2016 at Junagadh (Gujarat) to evaluate some cow-based bio-enhancers (Panchagavya, Bijamrut, Jivamrut, Amrutpani, Sanjivak and cow urine) and botanicals (Seaweed extract and Banana pseudo stem sap) for organic cultivation of summer groundnut. The results revealed that application of FYM @ $5 \mathrm{t} \mathrm{ha}^{-1}$ produced significantly higher pod (1653 kg ha-1) and haulm ( $3387 \mathrm{~kg} \mathrm{ha}^{-1}$ ) yields, followed by panchagavya as foliar spray @ 3\% at 30, 45 and 60 DAS (1397 and 2954 kg ha-1), and seaweed extract as foliar spray @ 3.5\% at 30, 45 and 60 DAS (1200 and $\left.2623 \mathrm{~kg} \mathrm{ha}^{-1}\right)$. While significantly the lowest pod (504 kg ha-1) and haulm $\left(2108 \mathrm{~kg} \mathrm{ha}^{-1}\right)$ yields were recorded under the control.

Keywords: Amrutpani, bijamrut, cow urine, jivamrut, panchagavya, sanjivak, seaweed

\section{Introduction}

Recognizing the adverse impact of excessive use of chemicals on soil health, human health and environment, Government of India promoting organic farming through various projects and schemes. Organic farming has been included as special category of farming in the National Agriculture Policy approved by the Government of India during 2000. Recently the Government of Gujarat declared "Gujarat Organic Farming Policy-2015" to support scientifically evolved organic farming practices for sustainable farming system along with the trustworthy marketing and supply chain of the produce. It is aimed to promote technically sound, economically viable, environmentally non-degrading, and socially acceptable use of natural resources in favour of organic agriculture. The policy seeks to actualize the area and crop potential for organic farming, sustaining soil fertility, conserving bio-resources, strengthening rural economy, promoting value addition, accelerating the growth of agro-business and securing a fair standard of living for the farmers and agricultural workers and their families. For effective implementation of the policy, there is an urgent need to develop a composite package of practices for major crops of the region. Number of cow-based bio-enhancers like 'Bijamrut', 'Jivamrut', 'Panchagavya', 'Amrutpani', 'Sanjivak' etc. have been developed in different organic farming systems by innovative organic growers or associations and NGOs. But very meagre scientific information is available regarding such formulations. National Centre for Organic Farming and National Horticulture Mission included such cow-based bio-enhancers in package of practices for organic cultivation of different crops. Banana pseudo stem sap and seaweed extract have been recommended by agricultural universities. These products can be incorporated in organic farming module. Considering these points in view, the present experiment is proposed to test the efficacy of some cowbased bio-enhancers and botanicals for organic cultivation of summer groundnut.

\section{Materials and Methods}

A field experiment was conducted at Organic Farming Research Farm, Department of Agronomy, College of Agriculture, Junagadh Agricultural University, Junagadh (Gujarat) in summer season of 2016. The soil of the experimental plot was clayey in texture and slightly alkaline in reaction as well as low in available nitrogen, available phosphorus and medium in available potash. The experiment comprising of 10 treatments viz., $\mathrm{T}_{1}$ : Panchagavya as foliar spray @ 3\% at 30, 45 and 60 DAS, T. : Bijamrut as seed treatment @ $300 \mathrm{ml}$ $\mathrm{kg}^{-1}$ seed, $\mathrm{T}_{3}$ : Jivamrut @ $500 \mathrm{~L} \mathrm{ha}^{-1}$ with irrigation at sowing, 30 and 45 DAS, T : Amrut pani @ $500 \mathrm{~L} \mathrm{ha}^{-1}$ with irrigation at sowing, 30 and 45 DAS, $\mathrm{T}_{5}$ : Sanjivak @ $500 \mathrm{~L} \mathrm{ha}^{-1}$ with irrigation at sowing, 30 and 45 DAS, $T_{6}$ : Seaweed extract as foliar spray @ 3.5\% at 30, 45 and 60 DAS, $T_{7}$ : Banana sap as foliar spray @ 1\% at 30, 45 and 60 DAS, $\mathrm{T}_{8}$ : Cow urine @ $500 \mathrm{~L} \mathrm{ha}^{-1}$ with 
irrigation at sowing, 30 and 45 DAS, T. FYM @ 5 t ha-1, and $\mathrm{T}_{10}$ : Control was laid out in randomized block design with three replications. The gross and net plot size were 5.0x2.4 $\mathrm{m}^{2}$ and $4.0 \times 1.8 \mathrm{~m}^{2}$, respectively. The ground nut variety "GJG31 " was sown at $30 \times 10 \mathrm{~cm}^{2}$ using seed rate of $120 \mathrm{~kg} \mathrm{ha}^{-1}$. The cow-based formulations were prepared on farm as per the procedure given by National Centre for Organic Farming, Ghaziabad (NCOF, 2006).

\subsection{Panchagavya}

Collect fresh cow dung (5 kg), mix it with ghee ( $1 \mathrm{~L})$ and keep it in a plastic barrel separately for three days. On the same day, mix the other ingredients, namely cow urine $(3 \mathrm{~L})$, cow's milk (2 L), curd (2 L), yellow banana (400 g, without skin), coconut water $(3 \mathrm{~L})$, jaggery (1 kg dissolved in $3 \mathrm{~L}$ water) in a plastic barrel separately. Filter the jaggery solution before adding it to the other ingredients. On the third day, mix the contents of both the barrels and leave them aside for seven days. Stir the contents with a wooden stick twice a day. After seven days, filter the product with a khada or terracot (TC) cloth and store it in closed containers (Pierce small holes in the cap of the containers to prevent bursting). This is diluted @ $300 \mathrm{ml} 10 \mathrm{~L}^{-1}$ water and sprayed.

\subsection{Bijamrut}

Mix cow dung $5 \mathrm{~kg}$, cow urine $5 \mathrm{~L}$, cow milk $1 \mathrm{~L}$, lime $50 \mathrm{~g}$, water $20 \mathrm{~L}$ and handful soil from rhizosphere area of banyan tree and keep overnight. Sprinkle the formulation on seeds to be sown, then dry in the shade before sowing.

\subsection{Jivamrut}

Take $100 \mathrm{~L}$ water in barrel and add $10 \mathrm{~kg}$ cow dung+10 L cow urine. Mix well with the help of a wooden stick, add $2 \mathrm{~kg}$ old jaggery and $2 \mathrm{~kg}$ pulse flour (gram, pigeon pea, greengram, cowpea or blackgram) and handful soil from rhizosphere area of banyan tree. Mix this solution well with a wooden stick. Keep the solution aside for fermentation for two to seven days. Shake the solution regularly three times a day.

\subsection{Amrut pani}

Mix $10 \mathrm{~kg}$ cow dung with $500 \mathrm{~g}$ honey and mix thoroughly to form a creamy paste. Add $250 \mathrm{~g}$ of ghee and mix at high speed. Dilute with $200 \mathrm{~L}$ water. Sprinkle this suspension in one acre over soil or with irrigation water.

\subsection{Sanjivak}

Mix $100 \mathrm{~kg}$ cow dung, $100 \mathrm{~L}$ cow urine and $500 \mathrm{~g}$ jaggary in $300 \mathrm{~L}$ water in a $500 \mathrm{~L}$ closed drum. Ferment for 10 days. Used as soil application either by sprinkling or by applying through irrigation water. Three applications are needed one before sowing, second after 30 days of sowing and third after 45 days of sowing.

The banana pseudo stem extract was acquired from Soil and Water Management Unit, Navsari Agricultural University, Navsari and seaweed extract (Kappaphycus alvarezii) from Fisheries Research Station, Junagadh Agricultural University,
Okha. Foliar spraying was done using knapsack sprayer with spray volume of $500 \mathrm{~L} \mathrm{ha}^{-1}$. The crop was raised as per organic standards in organically converted plot. Pest and disease protection measures were taken using organic or bio-pesticides.

\section{Results and Discussion}

Data presented in Table 1 showed that growth, yield and quality attributes viz., plant height, number of mature pods plant $^{-1}, 100$-kernel weight, shelling outturn and oil content of kernel significantly influenced by different treatments. Significantly the highest plant height $(46.79 \mathrm{~cm})$ was recorded with application of FYM @ $5 \mathrm{t} \mathrm{ha}^{-1}\left(\mathrm{~T}_{9}\right)$, which remained statistically at par with panchagavya as foliar spray @ 3\% at 30, 45 and 60 DAS $\left(T_{1}\right)$ and seaweed extract as foliar spray @ $3.5 \%$ at 30,45 and 60 DAS $\left(\mathrm{T}_{6}\right)$ having plant height of 45.53 and $45.18 \mathrm{~cm}$, respectively. The control $\left(T_{10}\right)$ registered significantly the lowest plant height $(37.41 \mathrm{~cm})$.

An application of FYM @ $5 \mathrm{t} \mathrm{ha}^{-1}\left(\mathrm{~T}_{9}\right)$ produced significantly the highest number of mature pods plant ${ }^{-1}(17.32)$, however it was found statistically comparable to panchagavya as foliar spray @ 3\% at 30, 45 and 60 DAS $\left(T_{1}\right)$, seaweed extract as foliar spray @ 3.5\% at 30, 45 and 60 DAS $\left(\mathrm{T}_{6}\right)$, Banana sap as foliar spray @ 1\% at 30, 45 and 60 DAS $\left(\mathrm{T}_{7}\right)$ and Jivamrut @ $500 \mathrm{~L} \mathrm{ha}^{-1}$ with irrigation at sowing, 30 and 45 DAS $\left(\mathrm{T}_{3}\right)$ with $16.94,16.37,15.42$ and 15.28 pods plant $^{-1}$, respectively. Again, significantly the lowest number of mature pods plant ${ }^{-1}$ (13.29) was noted with the control $\left(T_{10}\right)$.

The 100-kernel weight was found maximum (53.22 g) with application of FYM @ $5 \mathrm{t} \mathrm{ha}^{-1}\left(\mathrm{~T}_{9}\right)$, but it was remained statistically at par with panchagavya as foliar spray @ 3\% at 30, 45 and 60 DAS $\left(T_{1}\right)$ having test weight of $50.69 \mathrm{~g}$. While, the minimum test weight of $39.44 \mathrm{~g}$ was observed with the control $\left(\mathrm{T}_{10}\right)$.

The application of FYM @ $5 \mathrm{t} \mathrm{ha}^{-1}\left(\mathrm{~T}_{9}\right)$, foliar spray of panchagavya@3\% at 30, 45 and 60 DAS $\left(T_{1}\right)$ and seaweed extract $3.5 \%$ at 30,45 and $60 \mathrm{DAS}\left(\mathrm{T}_{6}\right)$, being statistically at par with each other, recorded significantly higher shelling of 70.86, 68.94 and $67.86 \%$, respectively. On the other hand, the control $\left(T_{10}\right)$ has significantly the lowest shelling outturn (60.61\%).

Significantly the highest oil content of kernel (49.80\%) was recorded with application of FYM @ $5 \mathrm{t} \mathrm{ha}^{-1}\left(\mathrm{~T}_{9}\right)$, which remained statistically at par with panchagavya as foliar spray @ 3\% at 30, 45 and 60 DAS $\left(T_{1}\right)$ and seaweed extract as foliar spray @ 3.5\% at 30, 45 and 60 DAS $\left(\mathrm{T}_{6}\right)$ by recordingoil content of 49.64 and $49.51 \%$, respectively. The control $\left(T_{10}\right)$ registered significantly the lowest kernel oil content (46.13\%).

FYM might have improved physical, chemical and biological properties of soil and ultimately provided congenial soil environment for better nutrients and water uptake by plant, which enhanced growth and yield attributes of groundnut. The panchagavyais considered to be the most effective bioenhancer, which might have enhanced photosynthesis and 
partitioning of photosynthates to various metabolic sinks and resultantly promoted growth and yield components. The seaweed composed of various plant hormones, which might have been responsible for improved growth and development of groundnut. These results are in conformity with findings of Rao et al. (2015); Gayathri et al. (2015) for panchagavya in vegetables, and with those of Kavipriya et al. (2011); Jadhao et al. (2015) for seaweed extract in green gram and black gram. The data furnished in Table 1 further showed that significantly the highest pod (1653 kg ha-1) and haulm (3387 kg ha-1) yields of groundnut were registered with application of FYM @ 5 t ha-1 $\left(T_{9}\right)$, however it was found statistically equivalent to panchagavya as foliar spray @ 3\% at 30, 45 and 60 DAS $\left(\mathrm{T}_{1}\right)$ and seaweed extract as foliar spray @ 3.5\% at 30, 45 and 60 DAS $\left(T_{6}\right)$. These treatments increased 228, 217 and $190 \%$ pod yield and 61, 50 and $43 \%$ haulm yield over the control, respectively. Improved growth and yield attributes under these treatments might have responsible for increased yield. The results corroborate the findings of Patel et al. (2013); Panchal et al. (2017) in respect of panchagavya in cowpea and chickpea, and those of Rathore et al. (2009) and Dogra and Mandradia (2012) in case of seaweed extract in soybean and onion.

\begin{tabular}{|c|c|c|c|c|c|c|c|}
\hline Treatment & $\begin{array}{c}\text { Plant height } \\
(\mathrm{cm})\end{array}$ & $\begin{array}{c}\text { Mature pods } \\
\text { plant }^{-1}\end{array}$ & $\begin{array}{l}\text { 100-kernel } \\
\text { weight (g) }\end{array}$ & $\begin{array}{c}\text { Shelling } \\
(\%)\end{array}$ & $\begin{array}{c}\text { Oil content } \\
(\%)\end{array}$ & $\begin{array}{c}\text { Pod yield } \\
\left(\mathrm{kg} \mathrm{ha}^{-1}\right)\end{array}$ & $\begin{array}{l}\text { Haulm yield } \\
\qquad\left(\mathrm{kg} \mathrm{ha}^{-1}\right)\end{array}$ \\
\hline $\mathrm{T}_{1}:$ Panchgavya & 45.53 & 16.94 & 50.69 & 68.94 & 49.64 & 1597 & 3154 \\
\hline $\mathrm{T}_{2}:$ Bijamrut & 39.24 & 14.46 & 40.57 & 63.42 & 47.75 & 679 & 2257 \\
\hline $\mathrm{T}_{3}:$ Jivamrut & 42.57 & 15.28 & 43.88 & 65.27 & 48.02 & 1037 & 2456 \\
\hline $\mathrm{T}_{4}:$ Amrutpani & 42.91 & 14.59 & 43.49 & 64.47 & 48.04 & 994 & 2450 \\
\hline $\mathrm{T}_{5}:$ Sanjivak & 40.19 & 14.53 & 42.57 & 64.33 & 47.58 & 806 & 2357 \\
\hline $\mathrm{T}_{6}:$ Seaweed extract & 45.18 & 16.37 & 45.11 & 67.86 & 49.51 & 1463 & 3023 \\
\hline $\mathrm{T}_{7}$ : Banana sap & 43.46 & 15.42 & 44.28 & 66.67 & 47.43 & 1096 & 2510 \\
\hline $\mathrm{T}_{8}:$ Cow urine & 39.78 & 14.17 & 41.39 & 63.45 & 47.11 & 723 & 2301 \\
\hline $\mathrm{T}_{9}: \mathrm{FYM}$ & 46.79 & 17.32 & 53.22 & 70.86 & 49.80 & 1653 & 3387 \\
\hline $\mathrm{T}_{10}:$ Control & 37.41 & 13.29 & 39.44 & 60.61 & 46.13 & 504 & 2108 \\
\hline $\mathrm{CD}(p=0.05)$ & 1.78 & 2.62 & 2.95 & 3.16 & 1.72 & 227 & 429 \\
\hline
\end{tabular}

\section{Conclusion}

Foliar spraying of panchagavya and seaweed extract were found as good as soil application of FYM. Hence, it can be concluded that in paucity of FYM, higher yield of summer groundnutgrown under organic condition could be achieved by foliar spray of panchagavya@ 3\% or seaweed extract @ $3.5 \%$ at 30,45 and 60 DAS on medium black clayey soil under South Saurashtra Agro-climatic Zone.

\section{References}

Dogra, B.S., Mandradia, R.K., 2012. Effect of seaweed extract on growth and yield of onion. International Journal of Farm Sciences 2(1), 59-64.

Gayathri, V., Nesiriya, M., Karthika, A., Sebastian, J., 2015. Study on the growth of vegetable crops using panchagavya. International Journal of Current Research 7(10), 21093-21096.

Jadhao, G.R., Chaudhary, D.R., Khadse, V.A., Zodape, S.T., 2015. Utilization of seaweeds in enhancing productivity and quality of black gram [Vigna mungo (L.) Hepper] for sustainable agriculture. Indian Journal of Natural Products and Resources 6(1), 16-22.

Kavipriya, R., Dhanalakshmi, P. K.,Jayashree, S.,Thangaraju, N.,
2011. Seaweed extract as a biostimulant for legume crop, green gram. Journal of Ecobiotechnology 3(8), 16-19.

NCOF, 2006. Package of Practices from Tamil Nadu for Organic Cultivation of Rice, Groundnut, Tomato and Okra. National Centre for Organic Farming (NCOF), Ghaziabad (http://ncof.dacnet.nic.in/).

Panchal, P., Patel, P.H., Patel, A.G., Desai, A., 2017. Effect of panchagavya on growth, yield and economics of chickpea (Cicer arietinum). International Journal of Chemical Studies 5(2), 265-267.

Patel, M.M., Patel, D.M., Patel, K.M., 2013. Effect of panchagavya on growth and yield of cowpea [Vigna unguiculata (L.) Walp.]. AGRES - An International e-Journal2(3), 313-317.

Rao, M.R.K., Kumar, M.S., Jha, N.K., 2015.Comparative yield analysis of chilli (Capsicum annuum L.) by application of vermicompost and panchagavya. Journal of Chemical and Pharmaceutical Research 7(9), 319-323.

Rathore, S.S., Chaudhary, D.R., Boricha, G.N., Ghosh, A., Bhatta, B.P., Zodape, S.T., Patolia, J.S., 2009. Effect of seaweed extract on the growth, yield and nutrient uptake of soybean (Glycine max) under rainfed conditions. South African Journal of Botany 75(2), 351-355. 